\title{
NOTES ON THE INCIDENCE OF WHEAT STEM RUST (PUCCINIA GRAMINIS TRITICI) AT TAMMISTO IN THE SUMMER OF 1958
}

\author{
ERKKI I. KIVI \\ Plant Breeding Station Tammisto of Hankkija, Helsingin pit. \\ Received November 1, 1958
}

Puccinia graminis has not occurred in Finland to any appreciable extent since the wheat stem rust epidemic of summer 1951 in Finland (2). It has been found every year in all spring wheat crops, though usually so late that the majority of the varieties have already had time to ripen and thus escape contamination. Rust has occurred in the very latest varieties and plant stands which for some reason ripened later than normal. Experiments in Sweden have shown that in spring wheat varieties deliberately sown considerably later than normal stem rust occurred on a scale that clearly showed the differences in resistance to the fungus between the varieties (3). In the summer of 1958, however, wheat stem rust occurred in the trial field of the Plant Breeding Station Tammisto even in the very earliest varieties and very extensively in the late, susceptible varieties. The disease was first observed around August 20, and by the middle of September, before the late plant stands had ripened, the most susceptible varieties were covered in rust.

Spring wheat ripened very late in 1958. Diamant wheat used as the standard variety has generally ripened at Tammisto about August 23. In 1958, ripening was not recorded until September 9 which was the latest ripening date for the entire trial period for this variety. It seems that the 1958 occurrence of wheat stem rust must be attributed chiefly to the lateness of growth. In the summer of 1951 ripening was also abnormally late, while stem rust had begun to appear considerably earlier than in summer 1958.

Table 1. The resistance of different spring wheat varieties to wheat stem rust at Tammisto in the summer of 1958. Classification according to (2, Table 3$)$.

Fully resistant: Cascade, Selkirk

Very resistant: Acadia, Canus, Carbo, Coronation, Regent, Renown, Saunders, Thatcher, K-32084 (Russian), Terä, Apu, Ta 4072, Ta 4690

Fairly resistant: Fasan, Gasser, Koga II, Redman, Svenno, Kimmo, Tammi, Touko

Susceptible: Diamant, Norröna, K-38516 (Russian), K-38535 (Russian), Ta 3291 
Distinct differences in resistance to wheat stem rust can be observed between the different varieties (Table 1). Only two Canadian varieties, Cascade and Selkirk, entirely escaped contamination. The majority of the very resistant varieties were American and were specially bred for resistance to wheat stem rust. Of these varieties, Saunders, Thatcher, Coronation, Redman and Canus were included among the varieties studied also during the 1951 epidemic (2, Table 3). Generally they proved both in 1951 and 1958 equally resistant to wheat stem rust. True Redman was less contaminated in 1951 than in 1958. The difference is considerable only as regards Canus wheat for according to observations made at the Jokioinen Plant Breeding Station it was susceptible in the summer of 1951 but very resistant in 1958 . Renown, which had transmitted a good resistance to wheat stem rust to its descendants in the trial field in summer 1951 (2, Table 5), proved very resistant to the disease in summer 1958.

The non-American spring wheat variety which showed the greatest resistance to stem rust in the summer of 1951, Terä from Tammisto, was again classed in the highly resistant group. In the same group came two Tammisto lines of which Ta4072 derives from the cross Jyvälahti $\times$ Ta752. Jyvälahti is a wheat variety which came to Finland from the USSR during the war and details of its origin are not known in Finland. It has been employed extensively in crosses and its descendants have generally proved very susceptible to rust. This is the case, for instance, with line Ta3291 (Kärn II $\times$ Jyvälahti). In Tammisto's pedigree material (Table 2) the origin Kimmo $\times$ Jyvälahti was the one most heavily infected by wheat stem rust and considerably more susceptible than Kimmo which was used as the standard variety in the present experiment. In addition to the above-mentioned, Tammisto trials were made with three Soviet varieties of spring wheat. Of these, K-32084 proved to be very resistant while the other two were heavily infected by rust. These varieties were obtained from Leningrad (VIR).

The very earliest domestic varieties seem, thanks to their earliness, to have escaped the worst rust contamination. Apu, a week earlier than Diamant wheat, was one of the highly resistant varieties although it was heavily infected in 1951 . It could be seen at the time (2) that Apu stands sown at the normal time escaped the heaviest contamination whereas late stands were heavily infected. Another indication of Apu's susceptibility to wheat stem rust is that origins in which Apu has been crossed with improved domestic variety have generally been heavily infected (Tables 2 and 3). Kimmo, when employed as the standard for pedigree material, was also infected more heavily than in the comparative trial on which the classification in Table 1 is based. In the comparative trial Kimmo ripened 5 days earlier than in the late pedigree sowings. Thanks to their earliness, domestic varieties which had been equally heavily infected in 1951 were now less contaminated than Diamant.

In the pedigree sowings as well as in young populations (Tables 2 and 3) the resistance to wheat stem rust of American varieties known to have this property emerged in their descendants in the same way as in the summer of 1951 at Jokioinen (2, Tables 5 and 6$)$. 
Table 2. The average resistance to wheat stem rust of some origins in Tammisto's pedigree material for 1958 .

$\begin{array}{lc}\text { Origin } & \begin{array}{r}\text { Resistance to } \\ \text { Puccinia }\end{array} \\ \text { graminis } \\ (10-0)\end{array}$

Table 3. Resistance to wheat stem rust of some $\mathrm{F}_{2}$ and $\mathrm{F}_{3}$ populations. (200 plants from each population).

\begin{tabular}{|c|c|c|c|c|}
\hline \multirow[t]{3}{*}{ Origin } & \multicolumn{4}{|c|}{ Resistance to Puccinia graminis } \\
\hline & Numb & plants & classes & Mean \\
\hline & $0-2$ & $3-6$ & $7-10$ & \\
\hline Ta $4721 \times$ Selkirk $F_{2}$ & & 12 & 178 & 7.8 \\
\hline Ta $4690 \times$ Regent $\mathrm{F}_{2}$ & & 33 & 167 & 7.8 \\
\hline Redman $\times$ Ta $3278 \mathrm{~F}_{3}$ & & 39 & 161 & 7.7 \\
\hline Apu $\times$ Redman $F_{3}$ & 4 & 35 & 161 & 7.7 \\
\hline Ta $4072 \times$ Acadia $\mathrm{F}_{2}$ & & 62 & 138 & 7.3 \\
\hline An $441 \times$ Kimmo $F_{3}$ & 46 & 124 & 30 & 4.3 \\
\hline Ta $3291 \times$ An $441 \mathrm{~F}_{3}$ & 105 & 94 & 1 & 2.7 \\
\hline $\mathrm{Apu} \times \mathrm{Ta} 3291 \mathrm{~F}_{3}$ & 154 & 43 & 3 & 1.9 \\
\hline
\end{tabular}

Biological races have not been studied at Tammisto, but specimens have been sent from Tammisto for inspection at the laboratory of the Swedish Seed Association in Svalöv. According to the analyses made there, the samples from Tammisto in the summer of 1956 were of race 21, one of the most common biological races of wheat stem rust in Europe (1). The similarity of the wheat stem rust observations made in two summers leads to the assumption that the same biological race, Puccinia graminis tritici, or at least two closely related races was dominant on each occasion. The conclusion drawn in Sweden on the basis of several years of observations is that in Sweden wheat stem rust has been more or less similar in its racial composition in successive years (3). 
Acknowledgement. The writer had at his disposal the spring wheat material of the Plant Breeding Station Tammisto. For this facility he wishes to thank his principal, Mr. E. Huttunen, M. Sc.

\section{REFERENCES}

(1) Gustavsson, A. 1957. Fysiologiska raser av stråsädesrost i Sverige 1956. Bot. Not. 110: 293-306.

(2) KIvı, E. I. 1956. The epidemic of wheat stem rust (Puccinia graminis tritici) on spring wheat in South-West Finland in 1951, primarily from the breeder's point of view. J. Sci. Agric. Soc. Finl. 28: 119-141.

(3) WÁlstedt, I. 1952. Erfarenheter rörande svartrostangreppet på vete i Sveriges Utsädesförenings Östgötafilials område och i försöken 1952. Lantbr. veckan 1952: 224-229.

SELOSTUS:

VEHNÄN MUSTARUOSTEEN ESIINTYMISESTÄ TAMMISTOSSA KESÄLLÄ 1958

ERKKI I. KIVI

Hankkijan kasvinjalostuslaitos Tammisto, Helsingin pit.

Kesällä 1958 esiintyi Tammiston koekentällä varsin runsaasti vehnän mustaruostetta. Esiintymän voimakkuus lienee laskettavissa lähinnä valmistumisajankohdan myöhäisyyden tilille. Elokuun loppupäivinä ilmaantunut ruoste ennätti saastuttaa kaikkein aikaisimpiakin lajikkeita. Eri lajikkeet saastuivat yleensä samalla tavoin kuin kesän 1951 epidemian aikana Jokioisissa (2). Näin ollen vaikuttaa siltä, että kumpanakin vuotena olisi pääasiallisin saastunnan aiheuttaja ollut sama mustaruosteen biologinen rotu tai ainakin lähisukuiset rodut. 